\title{
Dependence of the Stable Carbon Isotope of Planktic Foraminiferal Species Globigerina Bulloides on Food Supply in the Indian Ocean Sector of Southern Ocean
}

\author{
Neloy Khare \\ Ministry of Earth Sciences, Prithvi Bhawan, Lodhi Road, New Delhi - 110003, India \\ Email: nkhare45@gmail.com
}

\begin{abstract}
Twenty one surface sediment samples (comprising Peterson Grab, Piston, Gravity and Spade core top samples) were collected along a north-south transect (between $9.69^{\circ} \mathrm{N}$ and $55.01^{\circ} \mathrm{S}$ latitude and $80^{\circ} \mathrm{E}$ and $40^{\circ} \mathrm{E}$ longitude). These samples were used to study $\delta^{13} \mathrm{C}$ values in the calcareous shells of planktic foraminiferal species Globigerina bulloides and the variations were compared with the latitudinal changes in the overall size of the planktic foraminiferal population obtained from earlier published data along similar transect. The results establish an interdependence of $\delta^{13} \mathrm{C}$ values of planktic species Globigerina bulloides and the overall size of planktic foraminiferal population. The region where the $\delta^{13} \mathrm{C}$ values of planktic species Globigerina bulloides decrease the overall size of planktic foraminiferal population increases. Such a distinct pattern may be ascribed to the generation of food/nutritive material. It is suggested that similar studies to understand variations in $\delta^{13} \mathrm{C}$ values in foraminiferal shells and its population size in geographically distinct latitudinal corridors covering distinct marine regime of physico-chemical conditions be undertaken to further strengthen the argument proposed in the present study.
\end{abstract}

Keywords: Stable carbon isotope; planktic foraminifera; nutrient; Indian Ocean sector; southern ocean.

\section{Introduction}

The stable carbon isotopes of planktic foraminiferal tests have been used for paleooceanographic reconstructions [1-9]. A number of factors have been proposed to have control over the $\delta^{13} \mathrm{C}$ values of the calcareous foraminiferal shells such as, vertical movement of foraminifera during their life cycles, changes in symbiont photosynthetic and respiratory rates, productivity and/or food/nutrient availability $[10-17]$.

A north-south transect from lower to higher latitudes in the Indian Ocean sector of the Southern Ocean, encompasses characteristic oceanographic conditions with distinct watermasses, productivity, current systems, nutrient/food availability due to different photosynthetic rates, besides other hydrographic properties. These varied physico-chemical properties call for a detailed study along such a north-south transect to study the response and inter-dependence of $\delta^{13} \mathrm{C}$ values of calcareous shells of planktic foraminifera retrieved from the surface sediment samples from varied watermasses of different latitudinal corridors. Accordingly in the present paper we have attempted to study the interdependence of $\delta^{13} \mathrm{C}$ values of planktic foraminiferal species Globigerina bulloides with food availability expressed in terms of size variations of entire planktic foraminiferal population along said north-south transect.

\section{The Study Area}

The oceanographic region through which the present north-south transect passes is characterized by the poleward Agulhas current lying to its west, the east ward flowing Antarctic Circumpolar Current (ACC) on its south and equator ward flowing west Australian current on its east. The Sub-tropical Front (STF) is located at approximately $42-43^{\circ}$ South latitude in Central South Indian Ocean [18]. The region is characterized by sub-tropical anti-cyclonic gyres [19]. Details on various physical properties of the water 
column along the study area are already discussed in previous study [20-21]. The north Indian Ocean experiences several reversals [19, 22]. The westward flowing North Equatorial Current (NEC) is prominent in January and March. The South Equatorial Current (SEC) occupies the region south of $8^{\circ}$ South. Between these westward flow runs the Equatorial Counter Current (ECC). The STF separates the warmer and saltier watermasses of the sub-tropics from the cold, fresh, nutrient rich sub- Antarctic awtermasses.

\section{$3 \quad$ Materials and Methods}

A total of 21 recent sea surficial sediment samples (comprising Peterson grab, gravity and piston coretop samples), collected during the $199 \mathrm{C}$ and $200^{\text {th }}$ (also known as Pilot expedition to Southern Ocean) cruises of ORV Sagar Kanya, were used for the present study. Geographically this study area covers transect between $9.69^{\circ} \mathrm{N}$ and $55.01^{\circ} \mathrm{S}$ latitude and $80^{\circ} \mathrm{E}$ and $40^{\circ} \mathrm{E}$ longitude in the Indian Ocean Sector of the Southern Ocean (South western Indian Ocean). The locations of various stations are given in Figure 1. The calcium carbonate compensation depth and the lysocline in and around the study area lie below 4,400-4,700 meters water depth [23]. All samples were collected well above this water depth to avoid any dissolution effects on the tests of planktic foraminifers.

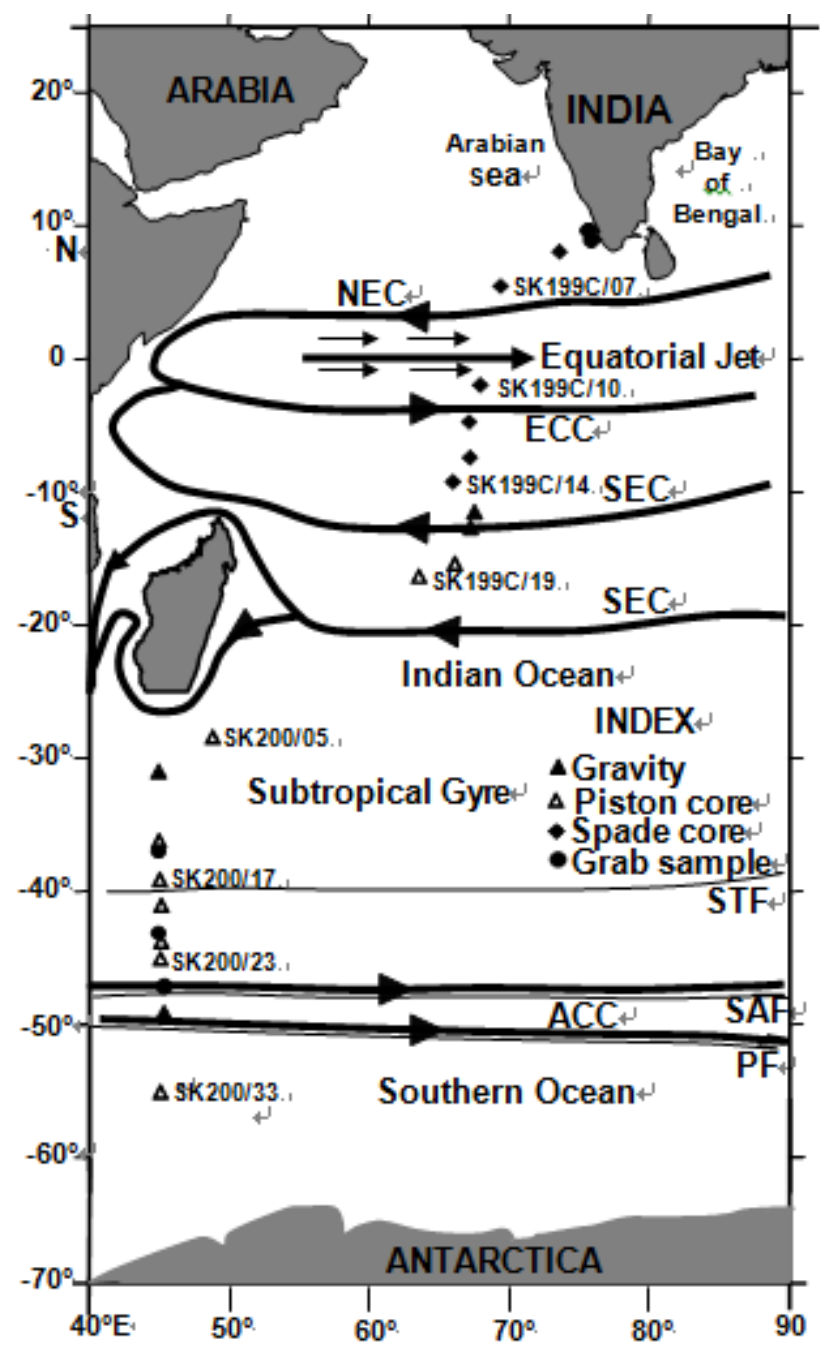

Figure 1. Map showing the locations of grab and core top samples. 
Immediately after recovery, the entire sediment samples (top $1 \mathrm{~cm}$ of the sediment core/grab) were stained with Rose Bengal and preserved in 10\% formalin to differentiate living specimen of benthic foraminifera. In the absence of exact age date for the sediment samples, the stained benthic foraminifers collected at various stations are considered to reflect modern ambient conditions at the seabed. About 5$10 \mathrm{~g}$ of sediments from each sample was first dried overnight at $45-50^{\circ} \mathrm{C}$. The dried samples were then soaked with water, which was decanted several times, and lastly filled with distilled water. $10 \mathrm{ml}$ of $10 \%$ sodium hexa-metaphosphate $\left[\mathrm{Na}\left(\mathrm{PO}_{3}\right)_{6}\right]$ was added to each of the samples to remove the clay materials. After that, the samples were processed over $63 \mu \mathrm{m}$ sieve with distilled water. The $>63 \mu \mathrm{m}$ material was dried at $45-50^{\circ} \mathrm{C}$. The $>63 \mu \mathrm{m}$ fraction was dry sieved to get $>150 \mu \mathrm{m}$ fraction. From the $>150 \mu \mathrm{m}$ fraction an aliquot was taken by coning and quartering. The representative samples were weighed and hence used for picking of minimum 10-12 specimen of the planktic indicator species Globigerina bulloides from each sample to measure the carbon isotopic composition $\left(\delta^{13} \mathrm{C}\right)$ at the Alfred Wegner Institute for Polar and Marine Research, Germany, with a Finnigan MAT 251 Isotope Ratio Gas Mass Spectrometer coupled to an automatic carbonate preparation device (Kiel I) and calibrated via NBS 19 to the PDB scale. The values are given in $\delta$-notation versus VPDB (Vienna Pee Dee Belemnite). Precision of carbon isotope measurements based on repeated analyses of a laboratory standard over a one-year-period was better than $0.06 \%$ for carbon.

\section{$4 \quad$ Results and Discussion}

Along the North-South transect in the Indian Ocean sector of Southern Ocean, the $\delta^{13} \mathrm{C}$ values in calcareous shells of planktic species Globigerina bulloides has varied from $-1.97 \%$ (at station SK200/09) to $0.673 \%$ (at station SK200/27). Figure 2 shows that carbon isotopic values $\left(\delta^{13} \mathrm{C}\right)$, exhibit a decreasing trend up to $30^{\circ} \mathrm{S}$ latitude and south of $30^{\circ} \mathrm{S}$ the profile is showing a general increasing trend. The profile of $\delta^{13} \mathrm{C}$ values considered in the present study looks interesting while compared with the already published profile of number of $>120 \mu \mathrm{m}$ sized planktic foraminiferal specimen in one gram sediments [24]. The comparison revealed a reverse pattern with a general increasing trend from $9.69^{\circ} \mathrm{N}$ to $30^{\circ} \mathrm{S}$ latitude and subsequently further south of $30^{\circ} \mathrm{S}$, it shows a general decreasing trend (Figures 2ab). It implies that there may be some common external factor for the ambient watermasses that could be conducive to enhance $\delta^{13} \mathrm{C}$ further south of $30^{\circ} \mathrm{S}$ latitude compared to the region lying north of $30^{\circ} \mathrm{S}$ latitudes. While the same factor is responsible towards general decrease in the population size south of $30^{\circ} \mathrm{S}$ compared to the shell size in the latitudinal corridor between $9.69^{\circ} \mathrm{N}$ and $30^{\circ} \mathrm{S}$. The distinct latitudinal changes in the profile of $\delta^{13} \mathrm{C}$ values and size of the planktic foraminiferal population could be explained in the light of the present oceanographic/hydrographic conditions of these latitudinal corridors.

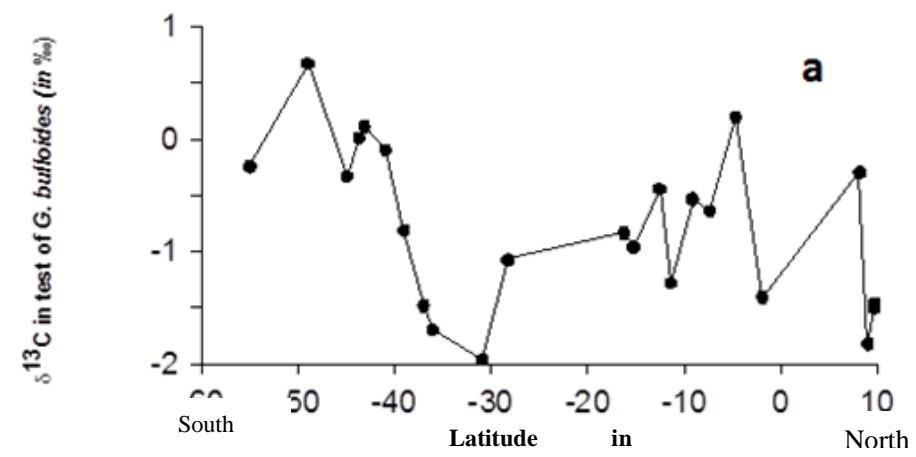

Figure 2a. Latitudinal changes in $\delta^{13} \mathrm{C}$ values in calcareous shells of planktic species G.bulloides. 


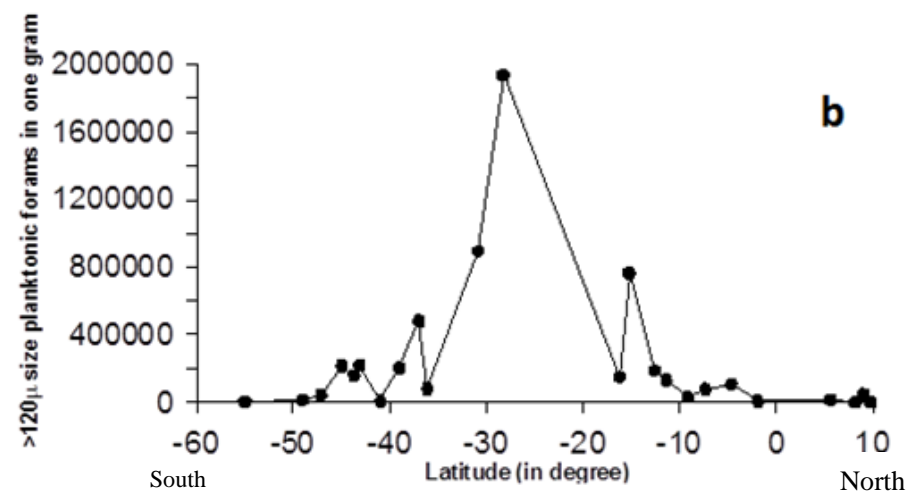

Figure 2b. Latitudinal changes in number of $>120 \mu \mathrm{m}$ sized planktic foraminiferal specimen [24].

During photosynthetic carbon fixation, nutrients and preferentially the light carbon isotope are utilized [25]. However due to decreased photosynthesis process ${ }^{26}$ in the region close to higher latitudes owing to low light intensity [26-27], the utilization of light carbon isotopes remain limited. This situation contributes towards an increase of $\delta^{13} \mathrm{C}$ values in the latitudinal corridor south of $30^{\circ} \mathrm{S}$ compared to the north of $30^{\circ} \mathrm{S}$. Such circumstances, in the higher latitude regions prompt a gradual reduction in the food availability giving rise to a continuous decrease in the overall size of the planktic foraminiferal population (Figure $2 \mathrm{~b}$ ).

It has been opined that nutritive material (phytoplankton) may influence the size of the foraminiferal tests and reduced phytoplankton may tend to result in under-sized specimen [28]. The organic matter flux (OMF) is primarily controlled by the phytoplankton production [29] and any changes in the production of phytoplankton affect the planktic foraminifer's nutrition [27]. Prevailing currents vis-à-vis availability of food (phytoplankton) for foraminiferal growth due to photosynthesis process, holds good to explain this characteristic pattern of $\delta^{13} \mathrm{C}$ values and size of planktic foraminiferal population (Figures $2 \mathrm{a}-\mathrm{b})$. In the region between around $15^{\circ} \mathrm{S}$ and $40^{\circ} \mathrm{S}$ latitudes major current systems [30] exist giving rise to increased size of planktic foraminiferal population with a decreasing trend of $\delta^{13} \mathrm{C}$ values due to consumption of lighter carbon isotope in the region north of $30^{\circ} \mathrm{S}$ latitude.

In conclusion the present results establish an interdependence of $\delta^{13} \mathrm{C}$ values of planktic species Globigerina bulloides and the overall size of planktic foraminiferal population linked with the generation of food/nutritive material. Since the present data set is limited to a specific sector (Indian Ocean) in the Southern Ocean and therefore, prior to comprehensively draw final inferences and establish proposed interdependence it becomes imperative to take up detailed study of the variations in $\delta^{13} \mathrm{C}$ values in foraminiferal shells and its population size in geographically distinct latitudinal corridors covering distinct marine regime of physico-chemical conditions.

Acknowledgements. The author is thankful to Dr.M.N. Rajeevan, Secretary, Ministry of Earth Sciences, Government of India, for his valuable encouragement and support to this study. Prof. A. Mackensen and Laboratory staff at Alfred Wegener Institute for Polar and Marine Research Bremerhaven, Germany, and Dr. Rajeev, Secretary, NIO, Goa are thankfully acknowledged for providing facilities for carbon isotope analyses. Master, officers and crew of ORV Sagar Kanya are acknowledged for providing logistics support during the collection of the samples.

\section{References}

1. O. Friedrich, J.O. Herrle, P.A. Wilson, M.J. Cooper, J. Erbacher, and C. Hemleben, "Early Maastrichtian carbon cycle perturbation and cooling event: Implications from the South Atlantic Ocean," Paleoceanography, vol. 24, PA2211, 2009. 
2. N.J. Shackleton and J.P. Kennett, "Paleotemperature history of the Cenozoic and the initiation of Antarctic glaciation: Oxygen and carbon isotope analysis in DSDP sites 277, 279, and 280 Initial Rep," Deep Sea Drill. Proj, vol. 29, pp. 743-755, 1975.

3. T.G. Li, R.T. Sun, D.Y. Zhang, Z.X. Liu, Q. Li and B. Jiang, "Evolution and variation of the Tsushima warm current during the late quaternary: Evidence from planktonic foraminifera, oxygen and carbon isotopes Science in China, Series D," Earth Sciences, vol. 50, pp. 725-735, 2007.

4. T. Li, Z. Liu, M.A. Hall, Y. Saito, S. Berne, S. Cang, Z. Cheng, "A broad deglacial $\delta^{13} \mathrm{C}$ minimum event in planktonic foraminiferal records in the Okinawa Trough," Chinese Science Bulletin, vol. 47, pp. 599-603, 2002.

5. B.K. Linsley, R.B. Dunbar, "The late Pleistocene history of surface water $\delta^{13} \mathrm{C}$ in the Sulu Sea: possible relationship to Pacific deepwater $\delta^{13} \mathrm{C}$ changes," Paleoceanography, vol. 9, pp. 317-340, 1994.

6. T. Pados, R.F. Spielhagen, D. Bauch, H. Meyer and M. Segl, "Oxygen and carbon isotope composition of modern planktic foraminifera and near-surface waters in the Fram Strait (Arctic Ocean) - a case study," Biogeosciences, vol 12, pp. 1733-1752, 2015.

7. P. Zang, R. Zuraida, J. Xu and C. Yang, "Stable carbon and oxygen isotopes of four planktonic foreminiferal species from core-top sediments of the Indonesian throughflow region and their significance," Acta Oceanologica Sinica, vol. 35, no. 10, pp. 63-75, 2016.

8. P F. Fraguas, K. B. Costa and F. A. L. Toledo, "Relationship between isotopic composition $\left(\Delta^{18} \mathrm{O}\right.$ and $\left.\Delta{ }^{13} \mathrm{C}\right)$ and plaktonic foraminifera test size in core tops from the Brazilian Continental Margin", Brazilian Journal of Oceanography, vol. 59, no.4, 2011, Available: Http://dx.doi.org/10.1590/S1679-87592011000400003.

9. W. Xiao, R. Wang, L. Polyak, A. Astakhov and X Cheng, "Stable oxygen and carbon isotopes in planktonic foraminifera Neogloboquadrina pachyderma in the Arctic Ocean: An overview of published and new surfacesediment data," Marine Geology, vol. 352, pp. 397-408, 2014.

10. D. Bauch, J. Carstens, and G.Wefer, "Oxygen isotope composition of living Neogloboquadrina pachyderma (sin.) in the Arctic Ocean," Earth and Planetary Science Letters, vol. 146, pp. 47-58, 1997

11. R.G. Fairbanks, P.H. Wiebeand and A.W.H. Be', "Vertical distribution and isotopic composition of living planktonic foraminifera in the Western North Atlantic," Science, vol. 207, pp. 61-63, 1980.

12. C. Hemleben, M. Spindler, and O.R. Anderson, Modern Planktonic Foraminifera, Springer, New York, 1989, pp. 363.

13. K.E. Kohfeld, R.G. Fairbanks, S.L. Smithand and I.D. Walsh,. "Neogloboquadrina pachyderma (sinistral coiling) as paleoceanographic tracers in polar oceans. Evidence from Northeast Water Polynya plankton tows, sediment traps, and surface sediments," Paleoceanography, vol. 11, pp. 679-699, 1996.

14. P.M. Kroopnick, "The distribution of C of SCO in the world oceans," Deep Sea Research Part A, vol. 32, pp. 57-84, 1985.

15. L.R. Sautter, and R.C. Thunell, "Seasonal variability in the $\delta \mathrm{O}$ and $\delta \mathrm{C}$ of planktonic foraminifera from an upwelling environment. Sediment trap results from the San Pedro Basin, southern California Bight," Paleoceanography, vol. 6, pp. 307-334, 1991.

16. J. Simstich, Die ozeanische Deckschicht des Europäischen Nordmeers im Abbild stabiler Isotope von Kalkgehäusen unterschiedlicher, Berichte Institut für Geowissenschaften University Kiel, Kiel, Germany, 1999, pp. 96.

17. H.J., Spero, I. Lerche, and D.F., Williams, "Opening the carbon isotope "vital effect' black box, 2, quantitative model for interpreting foraminiferal carbon isotope data," Paleoceanography, vol. 6, pp. 639-655, 1991.

18. L. Stramma, "The south Indian Ocean current," Journal of Physical Oceanography, vol. 22, pp. 325-347, 1992.

19. K. Wyrtki, Oceanographic Atlas of the International Indian Ocean Expedition, National Science Foundation, Washington D.C., 1971, pp. 531.

20. G.E.R. Deacon, "The hydrology of the Southern Ocean," Discovery Report, vol.15, pp. 1-24, 1937.

21. N. Anilkumar, M.K. Dash, A.J. Luis, B.V. Ramesh, Y.K. Somayajulu, M. Sudhakar and P.C. Pandey, "Oceanic front along $45^{\circ}$ east across Antarctic Circumpolar current during Austral summer 2004," Current Science, vol. 88, pp. 1669-1673. 2005.

22. N. Bahulayen, and C. Shaji, "Diagnostic model of 3-D circulation in the Arabian Sea and western equatorial Indian Ocean,". Proc. Indian Nat. Sci. Acad., vol. 62, pp. 325-347, 1996. 
23. V.K. Banakar, G. Parthiban, J.N. Pattanand P. Jauhari, "Chemistry of surface sediment along a north south transect across the equator in the central Indian basin: an assessment of biogenic and detrital influences on elemental burial of the sea floor" Chemical Geology, vol. 147, pp. 217-232, 1998.

24. N. Khare, and S.K. Chaturvedi, "Size variations of planktonic foraminiferal population in Indian Ocean sector of Southern Ocean," Indian Journal of Marine Sciences, vol. 35, pp. 221-226, 2006.

25. A. Mackensen, "Changing Southern Ocean palaeocirculation and effects on global climate," Antarctic Science, vol. 16, pp. 369-386, 2004.

26. C.M. Lali and T.R. Parsons, Biological Oceanography; An Introduction, $2^{\text {nd }}$ Edition, The Open University, Butterworth Heinemann, Oxford, 1997, pp. 314.

27. N. O. Eguchi, H. Kawahata, and A. Taira, "Seasonal response of planktonic foraminifera to surface ocean condition: Sediment trap results from the central North Pacific Ocean" J. Oceanogr, vol. 55, pp. 681-691, 1999.

28. E. Boltovskoy and R. Wright Recent foraminifera, Junk. The Hague, 1976, pp. 515.

29. S. Honjo, "Flux of particles to the interior of open ocean," in Particle Flux in the Ocean, (Eds.) Ittekot, V., Schafer, P., Honjo, S., and Depetris, P.J.) SCOPE 57, John Wiley \& Sons, Chichester. 1996, pp. 91-145.

30. M. Tomezak, and J.S. Godfrey, Regional Oceanography: An Introduction. Second Edition, Day Publication, Delhi, 2003, pp. 390 . 